\title{
CHRISTOPH CARDINAL SCHÖNBORN
}

The present volume embraces a theme of outstanding importance with its studies towards a Culture of Co-Existence in Pluralistic Societies in the Middle East and in India. In this very moment when the pluralistic framework of societies in the Middle East (to a much lesser degree in India) is in danger, it is of outmost importance to remember to the whole world community that the tradition and history of the Middle East is marked by a pluralist approach. Also, after the so-called Arab conquest, societies in the Middle East for a long time remained largely Christian. In one way or the other Christians and Muslims arranged a system of co-existence. We cannot understand the history of the countries of the Middle East without remembering those circumstances. Unfortunately, many of our contemporaries in the West are not aware of this reality.

Therefore, I am particularly grateful for the theme chosen by PRO ORIENTE. I do know that this topic was a suggestion of Mar Gregorios Youhanna Ibrahim, our dear friend for whose liberation - together with that of the Greek Orthodox Metropolitan of Aleppo, Mar Boulos Yazigi - we are continuously praying. Mar Gregorios has been an outstanding personality of the Oriental churches, a hero of Christianity in a dark contest.

My special thanks and appreciation go to Archbishop Mar Joseph Powathil, founding member of the PRO ORIENTE Forum Syriacum. His great commitment for dialogue within the Churches of Syriac Tradition and for the Ecumenical Movement and his active concern for the poor are rooted in his deep spirituality. 


\section{CHRISTOPH CARDINAL SCHÖNBORN}

I am sure that our common prayers are powerful for all the Christians and the people of good will who are victims of violence of the war in Syria. We implore Our Father in Heaven to grant peace and tranquility to the suffering people of Syria and the other countries of the Middle East.

Christoph Cardinal Schönborn

Archbishop of Vienna

President of the board of trustees of PRO ORIENTE 